\title{
Counting vultures at provisioned carcasses in Uganda
}

\section{Derek Pomeroy, George Kaphub, Dianah Nalwangac, Richard Ssemmandad, Bernard Lotukb, Andrew Opetob and Moses Matsikob}

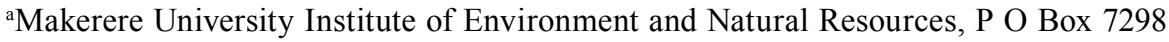
Kampala, Uganda

${ }^{b}$ Uganda Wildlife Authority, P O Box 3530, Kampala, Uganda

'Nature Uganda, P O Box 27034, Kampala, Uganda

${ }^{d}$ Wildlife Conservation Society, P O Box 7487, Kampala, Uganda

Corresponding author:derek@imul.com

\section{Introduction and Methods}

The plight of vultures means that it is important to monitor their numbers everywhere, so that efforts to save them can, where necessary, be made. This has been particularly so in India, but vultures are declining too in tropical Africa, including neighbouring Kenya (Ogada \& Keesing, 2010, Virani et al. 2010).

On the $26^{\text {th }}$ of January 2011, and again on the $26^{\text {th }}$ of January 2012, we repeated vulture counts in Uganda, using the same methods and sites as in 2009 (Pomeroy et al. 2011). These had followed a count in 2003 (Pomeroy et al. 2004) when, however, there were six sites instead of four, and when two goats were killed at each site, whereas from 2009 the carcasses were adult cows. In countries with known breeding sites of Gyps vultures, it is common practice to make nest counts as a means of monitoring; but no such sites are currently known in Uganda, although there are past records (Carswell et al. 2005).

Essentially, the method in both 2009 and 2011-2 was to slaughter a cow at an open, grassy site in each of Uganda's four savanna parks (see Table 1; details of the sites are given in Pomeroy et al., 2011) on the same day, and at approximately the same site in all years, since it was hoped that this would become a regular monitoring programme. The observers stationed their vehicle at 100-200 metres from the carcass, in a place with shade and a clear view of the carcass and surrounding trees. The cow was killed before $09 \mathrm{~h} 00$ wherever possible, and from then on, counts of vultures and other scavengers were made every 15 minutes until most of the vultures that came had also left. Some preliminary observations in 2009 suggested that the maximum count from these observations might still be less than the true maximum, since birds could both come and go within a 15 -minute interval between counts. We therefore kept a separate record of all arrivals and departures at one site (Murchison Falls) in 2011, irrespective of time.

http://dx.doi.org/10.4314/vulnew.v62i1.2 
Vultures soaring high overhead were not included in the counts, but those considered to be in the process of arriving or leaving, or perched in nearby trees, were counted. At Murchison Falls in 2012, there were two natural kills within 3-4 km of our carcass, both with vultures which have been included in the count as none came to our site.

\section{Results and Discussion}

It was encouraging to find that the total counts in 2011 and 2012 were higher than in previous years (Table 1), with increases in both Gyps species, particularly Rüppell's, whose numbers in Murchison Falls National Park are now comparable to those of the White-backed. Numbers for all other species were small and showed no clear trends. Overall, we recorded an increase in vulture numbers of exactly 100 , or $38 \%$, between 2003 and 2012, although this figure would be much less without the inclusion of vultures up to $5 \mathrm{~km}$ away in MFNP, as mentioned above.

In 2011 the opportunity was taken, on the same day as the other counts, to count birds at a site that had previously been used only in 2003 (Ishasha in Queen Elizabeth National Park); these results appear in Table 2. The increases here are remarkable - but are probably explained by the fact that, in 2011, there was an elephant carcass some $8 \mathrm{~km}$ away, where the vultures had been feeding for five days previously. Indeed, they were so gorged that although they gathered near the cow carcass, none actually fed on it. To provide a wider perspective, Table 2 also shows the average numbers of vultures in QENP as a whole, at naturally-occurring carcasses, and over a 10 -month period, and numbers at Ishasha in the months preceding the count. These show that typical numbers of White-backed Vultures, although quite large, were well below the 156 of January 2011.

There is some evidence of a long-term decline of all vulture species in Uganda (Pomeroy et al, unpublished, which includes data from the 1960s) but the data here, over a relatively short period, suggest recent increases, although with considerable fluctuations. The effects of a nearby elephant carcass in the southern QENP site, and probable carcasses not far from our cows at two sites in 2009, suggest one main reason for these fluctuations, but with further counts in future years, longterm trends should become apparent. 


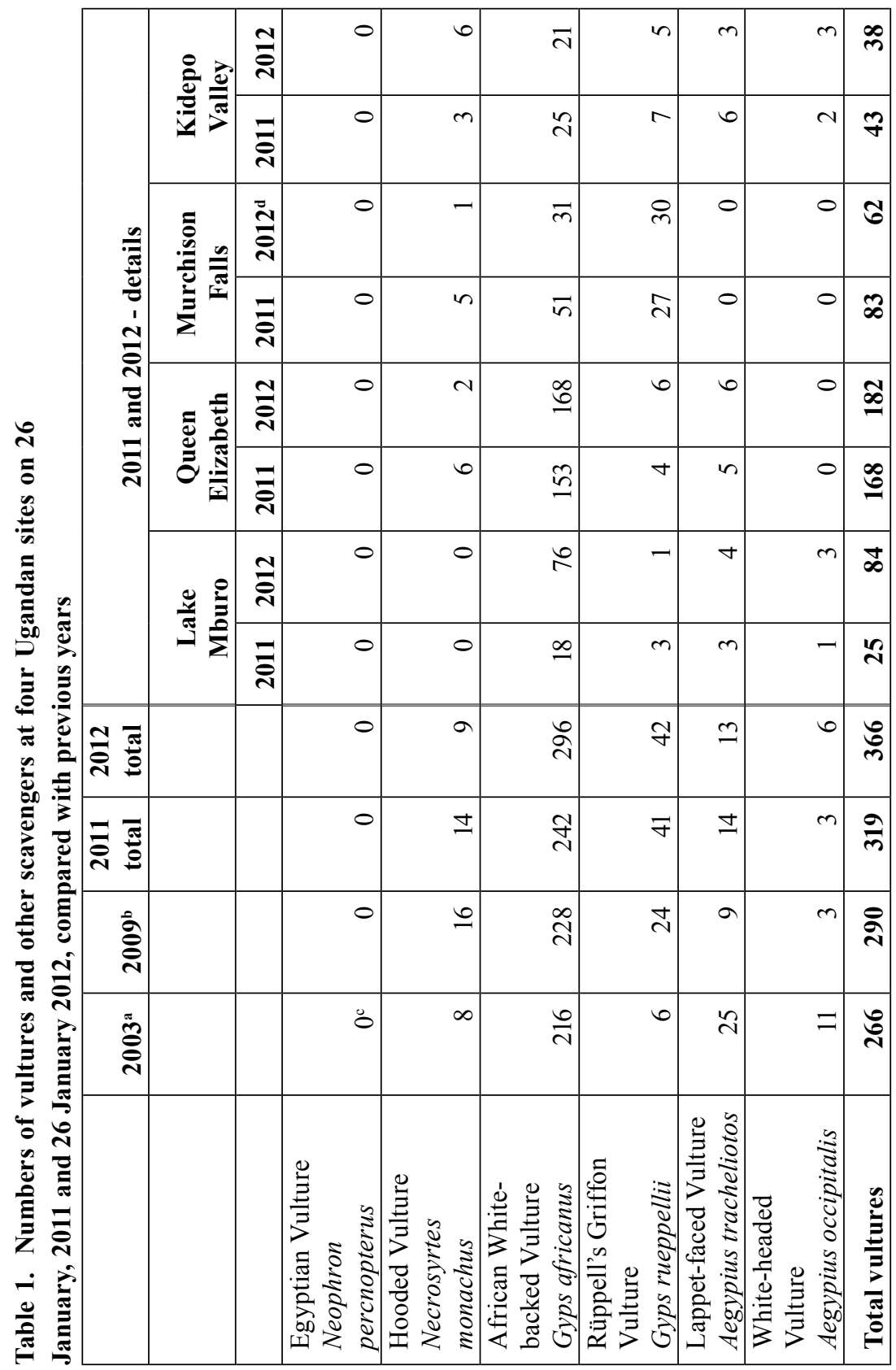




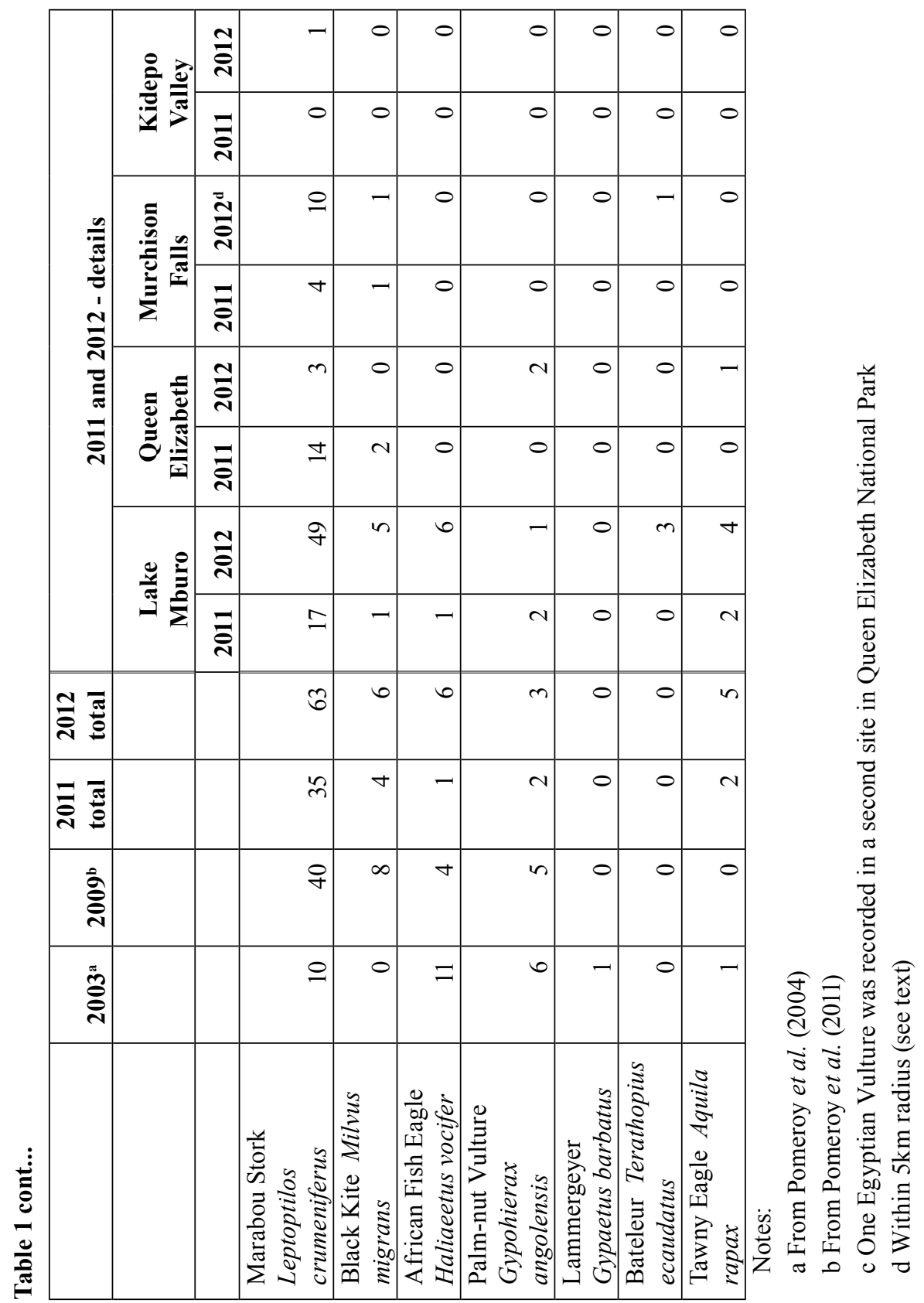


Recording all birds arriving and departing at the MFNP site (Table 3) showed that there were probably quite a lot more White-backed Vultures altogether than recorded at the carcass counts (several Hooded and Rüppell's Griffon Vultures were still there when the count ended, hence lower numbers for 'departures').
Combining the 2011 data for the two sites in QENP, there were over 300 White-backed Vultures, a considerable number for a park of some $2000 \mathrm{~km}^{2}$, surrounded on three sides by dense human settlement, although adjoining the Democratic Republic of Congo's Virunga Park to the west.

Table 2. Numbers of vultures attending carcasses in Queen Elizabeth National Park, Uganda. The first two columns are counts at cow carcasses. The remaining columns are data from a variety of animal species (see Table 4).

\begin{tabular}{|l|l|l|l|l|l|l|}
\hline \multicolumn{5}{|c|}{ Cow counts } & \multicolumn{1}{c|}{$\begin{array}{l}\text { Various } \\
\text { other } \\
\text { dates }\end{array}$} \\
\hline & $\mathbf{2 0 0 3}$ & $\mathbf{2 0 1 1}$ & Min & Max & Ave \\
\hline $\begin{array}{l}\text { Egyptian Vulture Neophron } \\
\text { percnopterus }\end{array}$ & 1 & 0 & 0 & 0 & 0 & 0 \\
\hline $\begin{array}{l}\text { Hooded Vulture Necrosyrtes } \\
\text { monachus }\end{array}$ & 0 & 14 & 11 & 1 & 16 & 5 \\
\hline $\begin{array}{l}\text { African White-backed Vulture } \\
\text { Gyps africanus }\end{array}$ & 31 & 156 & 71 & 28 & 161 & 46 \\
\hline $\begin{array}{l}\text { Rüppell's Griffon Vulture } \\
\text { Gyps rueppellii }\end{array}$ & 0 & 6 & 5 & 2 & 16 & 4 \\
\hline $\begin{array}{l}\text { Lappet-faced Vulture } \\
\text { Aegypius tracheliotos }\end{array}$ & 0 & 11 & 12 & 1 & 9 & 3 \\
\hline $\begin{array}{l}\text { White-headed Vulture } \\
\text { Aegypius occipitalis }\end{array}$ & 1 & 0 & 1 & 0 & 2 & 0 \\
\hline Total vultures & $\mathbf{3 3}$ & $\mathbf{1 8 7}$ & $\mathbf{1 0 0}$ & $\mathbf{3 2}$ & $\mathbf{2 0 6}$ & $\mathbf{5 8}$ \\
\hline $\begin{array}{l}\text { Marabou Stork Leptoptilos } \\
\text { crumeniferus }\end{array}$ & 3 & 16 & 9 & 2 & 16 & 5 \\
\hline $\begin{array}{l}\text { African Fish Eagle Haliaeetus } \\
\text { vocifer }\end{array}$ & 2 & 0 & 0 & 0 & 0 & 0 \\
\hline $\begin{array}{l}\text { Palm-nut Vulture Gypohierax } \\
\text { angolensis }\end{array}$ & 2 & 3 & 4 & 3 & 5 & 2 \\
\hline Tawny Eagle Aquila rapax & 0 & 1 & 3 & 1 & 4 & 1 \\
\hline
\end{tabular}

Notes: ${ }^{\mathrm{a}}$ Based on 114 counts between September 2010 and January 2011; ${ }^{\mathrm{b}}$ Based on 74 counts between September 2010 and June 2011 
Table 2 also shows that the average numbers of vultures attending fresh carcasses in the Ishasha area over a 5 -month period, at exactly 100 , was comparable to the numbers coming to cows over all sites in Uganda, suggesting that cow carcasses are suitable for experimental purposes. This is confirmed by the data in Table 4, showing vulture numbers at carcasses of various wild species. Numbers at cow carcasses were similar to those for Hippopotamus and Defassa Waterbuck, and considerably more than for other species. Vulture numbers at Ishasha are particularly high, perhaps because it adjoins the extensive Virunga National Park, in the Democratic Republic of Congo.

Table 3. A comparison of the maximum numbers of vultures as recorded at 15-minute intervals, and the totals of arrivals and departures, irrespective of time. Data from the 2011 count in Murchison Falls National Park

\begin{tabular}{|l|c|c|}
\hline & $\begin{array}{l}\text { Main } \\
\text { count }\end{array}$ & $\begin{array}{l}\text { Total arrivals and } \\
\text { departures }\end{array}$ \\
\hline Hooded Vulture Necrosyrtes monachus & 5 & $4 / 0$ \\
\hline African White-backed Vulture Gyps africanus & 51 & $78 / 78$ \\
\hline Rüppell's Griffon Vulture Gyps rueppellii & 27 & $29 / 24$ \\
\hline
\end{tabular}

Table 4. Mean numbers of vultures observed at 74 carcasses in Queen Elizabeth National Park (R. Ssemmanda and A. Plumptre, unpublished data).

\begin{tabular}{|l|c|c|c|c|c|c|}
\hline Species & $\begin{array}{c}\text { Elephant } \\
(\mathrm{n}=5)\end{array}$ & $\begin{array}{c}\text { Hippo- } \\
\text { potamus } \\
(\mathrm{n}=2)\end{array}$ & $\begin{array}{c}\text { Buffalo } \\
(\mathrm{n}=23)\end{array}$ & $\begin{array}{c}\text { Water- } \\
\text { buck } \\
(\mathrm{n}=4)\end{array}$ & $\begin{array}{c}\text { Topi } \\
(\mathrm{n}=3)\end{array}$ & $\begin{array}{c}\text { Kob } \\
(\mathrm{n}=37)\end{array}$ \\
\hline $\begin{array}{l}\text { African White- } \\
\text { backed Vulture }\end{array}$ & 30.4 & 93.0 & 44.5 & 79.3 & 22.3 & 19.2 \\
\hline $\begin{array}{l}\text { Lappet-faced } \\
\text { Vulture }\end{array}$ & 0.8 & 0.0 & 2.1 & 4.8 & 3.0 & 1.7 \\
\hline $\begin{array}{l}\text { White-headed } \\
\text { Vulture }\end{array}$ & 0.0 & 0.0 & 0.0 & 0.0 & 1.3 & 0.1 \\
\hline Rüppell's Vulture & 0.4 & 1.0 & 1.4 & 1.5 & 0.0 & 0.2 \\
\hline Hooded Vulture & 3.8 & 3.0 & 6.2 & 3.8 & 6.0 & 2.5 \\
\hline Palm-nut Vulture & 0.2 & 0.0 & 1.1 & 1.0 & 2.0 & 1.1 \\
\hline Total vultures & $\mathbf{3 5 . 6}$ & $\mathbf{9 7 . 0}$ & $\mathbf{5 5 . 3}$ & $\mathbf{9 0 . 4}$ & $\mathbf{3 2 . 6}$ & $\mathbf{2 4 . 8}$ \\
\hline
\end{tabular}


Some tentative conclusions, meanwhile, are:

- The method described here is relatively simple and repeatable; we suggest repetition every 2-3 years, funds permitting. The main cost is the cows, currently about \$250-300 each. January may not be the ideal month for counting vultures, since it is typically dry and food may then be fairly easily obtained, but teams were in the parks already for counts of waterbirds and other birds, thus saving travel costs.

- Considerable variations occur from year to year, such that trends are, as yet, not detectable with any degree of confidence. However, there does seem to have been a marked increase in Rüppell's Vultures in Murchison Falls. The overall increase in vulture numbers over the nine years (Table 1) seems encouraging, but it is obviously necessary to be cautious, because of the extent of the fluctuations already noted. However, it seems fairly safe to conclude that there was unlikely to have been any decline in this period.

- Counts in Kidepo Valley and Lake Mburo National Parks were undertaken entirely by staff of the Uganda Wildlife Authority, who also bought and transported the cows, and thus future counts could become entirely a UWA activity.

- It is clear that only small numbers of Hooded Vultures attend carcasses; this species is now almost entirely dependent on human refuse in towns and villages. Its biggest single population in Uganda is that of Kampala, with over 200 birds (Ssemmanda and Pomeroy, 2011) where, however, there has been a large decline over the past few years.

- Cows seem to be a satisfactory species to use for vulture counts, despite their cost.

\section{Acknowledgements}

Funding was provided mainly by The Peregrine Fund, and we are particularly grateful for that and for the participation of the Uganda Wildlife Authority, who also gave the necessary permissions. RS is partly funded by the Wildlife Conservation Society. Two reviewers are thanked for suggestions to previous versions of this article. 


\section{References}

Carswell, M., Pomeroy, D., Reynolds, J. \& Tushabe, H. 2005. Bird atlas of Uganda. British Ornithologists' Club and British Ornithologists' Union, London.

Ogada, D. L. \& Keesing, F. 2010. Decline of raptors over a 3-year period in Laikipia, Central Kenya. Journal of Raptor Research 44: 129-135

Pomeroy, D., Dranzoa, C., Anyii, P., Friday, T., Kaphu, G., Sande, E. \& Seifert, L. 2004. A vulture count in Uganda and a suggestion to other vulture-counters. Vulture News 50: 29-33.

Pomeroy, D., Byaruhanga, A., Kaphu, G., Opige, M., Masiko, M. \& Lutuk, B. 2011. A second count of vultures at carcasses in Uganda, and a revised proposal for a standardised method. Vulture News 60: 15-21.

Ssemmanda, R. \& Pomeroy, D. 2010. Scavenging birds in Kampala: 1973-2009. Scopus 30: 26-31.

Virani, M. Z., Kendall, C., Njoroge, P. \& Thomsett, S. 2010. Major declines in the abundance of Vultures and other scavenging raptors in and around the Masai Mara ecosystem, Kenya. Biological Conservation 144: 746-752. 